\title{
The Evaluation of Vaccine Hesitancy and Refusal for Childhood Vaccines and the COVID-19 Vaccine in Individuals Aged Between 18 and 25 Years
}

\section{8-25 Yaş Arası Bireylerde Çocukluk Çağı Aşıları ile COVID-19 Aşısına Yönelik Aşı Tereddüdü ve Reddinin Değerlendirilmesi}

\author{
(1) Gonca Soysal ${ }^{1}$, (1) Elif Durukan², (1) Recep Akdur² \\ ${ }^{1}$ Tokat Gaziosmanpasa University, Pazar Vocational School of Higher Education, Department of Health Care Services, Tokat, Turkey \\ ${ }^{2}$ Baskent University Faculty of Medicine, Department of Internal Medicine, Department of Public Health, Ankara, Turkey
}

Cite as: Soysal G, Durukan E, Akdur R. The Evaluation of Vaccine Hesitancy and Refusal for Childhood Vaccines and the COVID-19 Vaccine in Individuals Aged Between 18 and 25 Years. Turk J Immunol 2021;9(3):120-7

Received: 23.03.2021 Accepted: 18.11.2021

Corresponding Author: Gonca Soysal, Tokat Gaziosmanpasa University, Pazar Vocational School of Higher Education, Department of Health Care Services, Tokat, Turkey

Phone: +90 3562614341 E-mail: goncaakurtt@gmail.com ORCID: orcid.org/0000-0003-4158-4594

\begin{abstract}
Objective: The aim of this study is to determine vaccine hesitancy and refusal for childhood vaccines and the Coronavirus disease-2019 (COVID-19) vaccine in individuals aged between 18 and 25 years and the affecting factors.

Materials and Methods: In this descriptive study, an online questionnaire was implemented on 1.033 people aged between 18 and 25 years and living in Turkey between January 28, 2021, and February 19, 2021, by reaching them via e-mail and messaging applications.

Results: Among the participants, $68.8 \%$ considered getting their children vaccinated, $11.4 \%$ were hesitant and $3.1 \%$ refused. Among the participants, $36.6 \%$ considered getting vaccinated against COVID-19, 34.8\% hesitated and $28.6 \%$ refused. Hesitation/rejection of childhood vaccines increased with age and when negative information about childhood vaccines was obtained. The acceptance of the COVID-19 vaccine was higher in men, in those who assumed that the COVID-19 virus was of a natural origin, in those who obtained information on the COVID-19 vaccine from the Ministry of Health, and in those who made search in scientific papers.

Conclusion: The rates of hesitation and rejection in the COVID-19 vaccines are quite high compared to childhood vaccines. It shows that participants are influenced by speculative news. Therefore, it is recommended that this age group be given trainings based on scientific evidence regarding both childhood vaccines and the benefits of the COVID-19 vaccine.

Keywords: Vaccine hesitancy, vaccine refusal, vaccine acceptance, childhood vaccines, COVID-19 vaccine
\end{abstract}

$\ddot{\mathbf{O} z}$

Amaç: Bu çalışmanın amacı, 18-25 yaş arası bireylerde çocukluk çağı aşıları ile Koronavirüs hastalığı-2019 (COVID-19) aşısına yönelik aşı tereddüdü, reddi yaşama durumlarını ve bunlara etki eden faktörleri saptamaktır.

Gereç ve Yöntem: Tanımlayıcı tipteki bu araştırmada 28 Ocak 2021-19 Şubat 2021 tarihleri arasında Türkiye'de yaşayan 18-25 yaş arası 1.033 kişiye e-posta ve telefon mesaj uygulama araçları ile ulaşılarak online anket formu uygulanmıştır.

Bulgular: Katılımcıların \%68.8'i çocuklarına veya gelecekte çocukları olduğunda çocukluk çağı aşılarını yaptırmayı düşünürken \%3.1'i reddetmeyi düşünmektedir. Çocukluk çağı aşılarına karşı tereddüt yaşama durumları \%11.4'tür. Katılımcıların \%36.6'sı COVID-19 aşısını yaptırmayı düşünürken \%28.6'sı aşıyı reddetmeyi düşünmektedir. COVID-19 aşısını tereddüt edenlerin oranı ise \%34.8'dir. Çocukluk çağı aşılarının tereddüt/ ret durumları yaş ilerledikçe ve çocukluk çağı aşıları ile ilgili olumsuz bilgi edinildiğinde artmaktadır. COVID-19 aşısının kabulü, erkeklerde, COVID-19 virüsünün doğal kaynaklı olduğunu düşünenlerde, bilimsel araştırma makalelerinde araştırma yapanlarda ve Sağlık Bakanlığı'ndan bilgi edinenlerde daha yüksek bulunmuştur.

Sonuç: COVID-19 aşısındaki tereddüt ve ret oranları çocukluk çağı aşılarına göre oldukça yüksektir. Bu da katılımcıların spekülatif haberlerin etkisinde olduğunu göstermektedir. Bu nedenle bu yaş grubuna hem çocukluk çağı aşıları hem de COVID-19 aşısının yararlarıyla ilgili bilimsel kanıtlara dayalı eğitimlerin verilmesi önerilmektedir.

Anahtar Kelimeler: Aşı tereddüdü, aşı reddi, aşı kabulü, çocukluk çağı aşıları, COVID-19 aşıSı

ORCID: G. Soysal 0000-0003-4158-4594, E. Durukan 0000-0002-8579-5564, R. Akdur 0000-0002-9766-1117

${ }^{\circ}$ Copyright 2021 by the Turkish Society of Immunology. Turkish Journal of Immunology published by Galenos Publishing House.

Licenced by Creative Commons Attribution-NonCommercial-NoDerivatives 4.0 International (CC BY-NC-ND 4.0) 


\section{Introduction}

To increase the health level of people in a society, it is necessary to attach importance and priority to preventive health services. The health status of individuals can be improved and increased by avoiding factors that lead to diseases and taking measures ranging from adequate and balanced nutrition to creating a positive environment with immunization services. Undoubtedly, the full contribution and participation of people in a society in preventive health services through acceptable ways enable these services to be effective in individuals. ${ }^{[1]}$ Since preventive health services are offered to individuals when they are healthy due to their characteristics, these services may usually be interrupted due to many reasons at various points. In this context, it has been known for centuries that immunization among preventive health services reduces diseases' mortality and morbidity rates. ${ }^{[2]}$ However, due to the Coronavirus disease-2019 (COVID-19) vaccine, which has been recently on the agenda, the rapidly increasing discussions on the reliability and requirement of vaccination on printed and social media result in vaccine hesitancy and form a basis for the refusal of vaccination in Turkey and the world. ${ }^{[3]}$

In addition to significant claims that mercury in the content of vaccines leads to infertility and autism, and aluminum leads to autoimmune diseases and hyperactivity disorders in children, it is also often suggested that vaccines will damage the immune system of infants since their immune systems have not developed yet, that the immunity gained through infection with the actual disease will be disturbed, that vaccines have many side effects, that they are not necessary, and that they are produced by vaccine companies to make high profits. [4-6] Concerning the COVID-19 vaccine, criticisms on the vaccine development process have intensified due to the unnatural character of the virus, and although all stages have been completed successfully in a short time, many uncertainties and discussions have emerged with respect to how effective and safe this vaccine will be, the possibility that the virus may mutate again (while it is told to have already mutated a couple of times), and negate the vaccine's impact, and under what conditions and how fast billions of vaccines will be produced for the whole world. ${ }^{[7,8]}$ There were speculative news spreading fast on social media and stating that some people died in vaccine trials. These speculations cause individuals to be worried about the COVID-19 vaccine. ${ }^{[9]}$ Moreover, a study conducted simultaneously in Turkey and the UK put forward the effect of conspiracy theories on the COVID-19 vaccine. ${ }^{[10]}$ As revealed in the study, the belief that the virus was of a natural origin increased the vaccine acceptance by the participants, one in every three people in Turkey and $14 \%$ of the people in the UK hesitated, and $3 \%$ of the participants in both countries refused the vaccine. ${ }^{[10]}$

According to the World Health Organization (WHO), vaccine hesitancy is defined as the delay in the acceptance or as the refusal of vaccines despite the availability of vaccination services. Vaccine hesitancy influences individuals' motivation for their own vaccination or vaccination of their children and may cause them to refuse the vaccine. ${ }^{[11,12]}$ Vaccine hesitancy poses a threat for not only hesitant individuals but also society. Vaccine hesitancy and refusal reduce the immunity level of a society, and epidemics become inevitable in that society. Currently, vaccination is regarded as the solution for coping with the COVID-19 pandemic, which has influenced the whole world. Thus, it is anticipated that $50-60 \%$ of the population need to be vaccinated so that immunization studies can be successful.

According to the data of the WHO and the Turkish Ministry of Health, the 18-25 age group is not considered a group at risk for developing a severe disease during the pandemic. ${ }^{[13,14]}$ Known as emerging adulthood, the $18-25$ age group includes individuals' trials and decisions on their lives in many aspects, such as identity seek and change in their worldviews. ${ }^{[15]}$ In this respect, it is necessary to know the opinions of this age group since individuals' decisions on their own health and the health of their children start to be shaped in these years. As we have mentioned in the beginning, the success of health services in a society is possible with the full contribution and participation of individuals in that society. Since the hesitancy of individuals aged between 18 and 25 years against childhood vaccines and the COVID-19 vaccine may result in the refusal of vaccines, it is of great significance to know the vaccine refusal rates, the concerns and reasons behind their hesitancy, what increases their hesitancy, and why it results in vaccine refusal.

This study's purpose is to determine vaccine hesitancy and refusal for childhood vaccines and the COVID-19 vaccine in individuals aged between 18 and 25 years and the affecting factors.

\section{Materials and Methods}

In this descriptive study, an online questionnaire was applied to 1.033 people aged between 18 and 25 years and living in Turkey between January 28, 2021, and February 19,2021 , by reaching them via e-mail and messaging applications (In sample size calculation, at least 664 people were calculated at a $99 \%$ confidence interval and 0.01 deviation). To block multiple submissions in the online questionnaire, the participants signed in on Google to answer the questions. Forty-eight multiple submissions 
and 2 participations from outside Turkey were manually excluded from the data set.

In the study, the "Vaccine Hesitancy and Refusal Questionnaire" developed by the researcher based on the literature review was used as a data collection tool. This questionnaire was created by revising some questions in the Vaccine Hesitancy Questionnaire, developed by the working group of the WHO Strategic Advisory Group of Experts (SAGE). ${ }^{[10,16,17]}$ The questionnaire consists of 30 questions, including closed- and open-ended questions related to descriptive information and individuals' hesitancy, refusal, and opinions for childhood vaccines and the COVID-19 vaccine.

\section{Statistical Analysis}

As descriptive statistics, quantitative data were presented as mean and standard deviation, and qualitative data were given in numbers and percentages. In the statistical evaluation, the chi-squared test was conducted to compare the qualitative data. For each dependent variable, the independent variables-risk factors were tested by the binary logistic regression analysis. In the univariate analysis, the potential risk factors with $\mathrm{p}=0.20$ or lower were included in multivariate analyses, and a model was created for the logistic regression analysis. The value of $\mathrm{p}<0.05$ was considered significant.

The study data were transferred to the IBM SPSS version 20 statistics package and analyzed.

The approval of the Turkish Ministry of Health was obtained for the study. This study was approved by the Institutional Review Board of Baskent University (project no: KA21/33) and supported by the Research Fund of Başkent University.

\section{Results}

\section{Study Sample Characteristics}

The mean age of the participants was $21.09 \pm 2.01$ years. More than half of the participants were female $(68.8 \%)$ and single (93.5\%). Most of them had moderate economic status (66.8\%). Most participants had their childhood vaccines, and very few developed side effects after the vaccination $(79.8 \%, 3.0 \%)$ (Table 1). Among the participants, the first three side effects reported most frequently after the childhood vaccines were fever (74.2\%), pain/rash/swelling (48.4\%) at the injection site, and diarrhea/vomiting (19.4\%).

The Participants' Hesitancy and Refusal for the Vaccination of Their Children in Childhood and the Reasons for Their Hesitancy and Refusal

Among the participants, 711 (68.8\%) approved childhood vaccines for their children. While the participants refused childhood vaccines at a rate of $3.1 \%$, the hesitancy rate was $11.4 \%$ (Figure 1). The reason for vaccine refusal and hesitancy was mostly reported as not knowing the content of the vaccine. Most participants (74.6\%) believed that childhood vaccines could protect children from serious diseases. The ratio of the participants who wanted childhood vaccines to be mandatory was $50.1 \%$. The ratio of those who had heard or read negative information on childhood vaccines was $22.6 \%$ (Table 2). When they were asked about the negative information, they had received about childhood vaccines, the answers to the open-ended questions generally included information that vaccines were not reliable and domestic, that they caused disability and infertility, and that they contained substances that were not allowed religiously.

The Participants' Opinions and Exposures Regarding the COVID-19 Virus, Their Hesitancy and Refusal for COVID-19 Vaccination, and the Reasons for Their Hesitancy and Refusal

Of the participants, $61.9 \%$ thought that COVID-19 was an artificial virus. In the immediate environment of the participants, the number of people who died from COVID-19 or got sick severely was substantially high $(64.0 \%)$. The ratio of those who caught COVID-19 was $15.9 \%$. The information sources of the participants related to the COVID-19 vaccine mostly consisted of social media $(79.4 \%)$, while scientific research papers constituted the least used sources (34.6\%) (Table 3). Of the participants, $36.6 \%$ were thinking about having the COVID-19 vaccine, whereas $28.6 \%$ thought that they were going to refuse the vaccine. The ratio of individuals who hesitated was $34.8 \%$ (Figure 1). As the reason for refusal and hesitancy for the vaccine, "the short period of the research stages of the vaccine" was mostly reported. The ratio of the participants who wanted the COVID19 vaccine to be mandatory was $24.9 \%$. The ratio of those who had heard or read negative information on the COVID-19 vaccine was $57.9 \%$ (Table 3 ). The answers to the open-ended questions in which the content of the negative information on the COVID-19 vaccine was questioned consisted of negative information varying

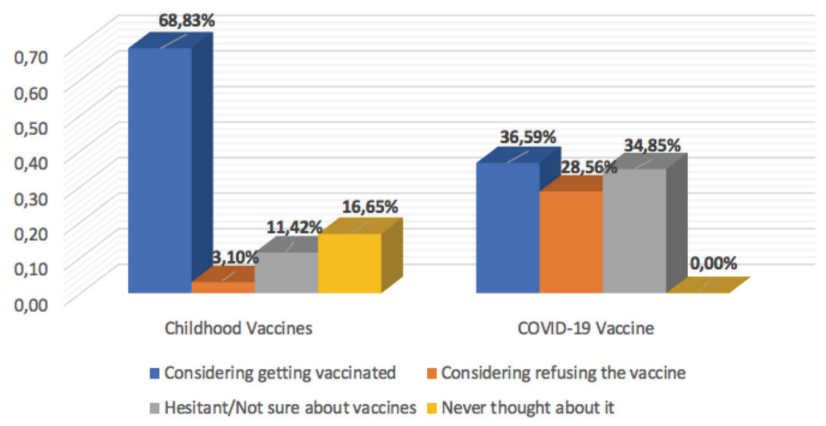

Figure 1. The participants' thoughts on childhood vaccinations and COVID-19 vaccination 
Table 1. The socio-demographic characteristics of the participants and information about childhood vaccination $(\mathrm{n}=1033)$.

\begin{tabular}{|c|c|}
\hline Variables & $\begin{array}{l}\mathrm{M} \pm \mathrm{SD} * \text { or } \\
\text { Number (percentage) }\end{array}$ \\
\hline Age (years) & $21.1 \pm 2.0$ \\
\hline \multicolumn{2}{|l|}{ Gender } \\
\hline Female & $710(68.7 \%)$ \\
\hline Male & $323(31.3 \%)$ \\
\hline \multicolumn{2}{|l|}{ Education level } \\
\hline Primary education & $15(1.5 \%)$ \\
\hline High school & $144(13.9 \%)$ \\
\hline Associate degree & $402(38.9 \%)$ \\
\hline Bachelor's degree & $455(44.0 \%)$ \\
\hline Master's degree & $17(1.5 \%)$ \\
\hline \multicolumn{2}{|l|}{ Economic status } \\
\hline Very good & $19(1.8 \%)$ \\
\hline Good & $231(22.4 \%)$ \\
\hline Medium & $690(66.8 \%)$ \\
\hline Poor & $79(7.6 \%)$ \\
\hline Very poor & $14(1.4 \%)$ \\
\hline \multicolumn{2}{|l|}{ Employment status } \\
\hline Employed & $103(10.0 \%)$ \\
\hline Unemployed & $108(10.5 \%)$ \\
\hline Student & $732(70.9 \%)$ \\
\hline Both a student and employed & $90(8.7 \%)$ \\
\hline \multicolumn{2}{|l|}{ Marital status } \\
\hline Married & $64(6.2 \%)$ \\
\hline Single & $969(93.8 \%)$ \\
\hline \multicolumn{2}{|l|}{ Status of having children } \\
\hline Yes & $42(4.1 \%)$ \\
\hline No & $991(95.9 \%)$ \\
\hline Number of children & $1.5 \pm 0.7$ \\
\hline \multicolumn{2}{|l|}{ Childhood vaccination } \\
\hline All vaccines were completed & $827(80.1 \%)$ \\
\hline Some vaccines were missing & $138(13.4 \%)$ \\
\hline No vaccination was performed & $9(0.9 \%)$ \\
\hline They did not know/remember & $59(5.7 \%)$ \\
\hline \multicolumn{2}{|c|}{ Development of side effects after vaccination in childhood } \\
\hline Yes & $31(3.0 \%)$ \\
\hline No & $767(74.2 \%)$ \\
\hline They do not know/remember & $235(22.7 \%)$ \\
\hline \multicolumn{2}{|c|}{$\begin{array}{l}\text { Development of side effects after vaccination in the environment } \\
\text { or relatives }\end{array}$} \\
\hline Yes & $85(8.2 \%)$ \\
\hline No & $418(40.5 \%)$ \\
\hline No idea & $530(51.3 \%)$ \\
\hline
\end{tabular}

*M: Mean, SD: Standard deviation from the concerns that the short period of the vaccine studies might cause severe side effects in the long run to severe side effects which might result in death.

Influencing Factors of Vaccination Acceptance and Refusal/Hesitancy in Childhood Vaccines and the COVID-19 Vaccine

The hesitancy/refusal for childhood vaccines increased as the age odds ratio (OR): $-0.12,95 \%$ confidence interval (CI): 0.79-0.99 advanced and negative information was received on childhood vaccines (OR: -1.22 , 95\% CI: 0.18 0.46). However, vaccination acceptance was 16.75 times higher in individuals who thought that childhood vaccines

Table 2. Opinions of the participants about childhood vaccines.

\begin{tabular}{ll}
\hline Variables & $\begin{array}{l}\text { Number } \\
\text { (percentage) }\end{array}$ \\
\hline
\end{tabular}

Their opinions about childhood vaccination for their current or future children

\begin{tabular}{ll}
\hline In favor of vaccination & $711(68.8 \%)$ \\
\hline Considering refusing the vaccine & $32(3.1 \%)$ \\
\hline Hesitant/not sure about vaccines & $118(11.4 \%)$ \\
\hline Never thought about it & $172(16.7 \%)$ \\
\hline \multicolumn{2}{l}{ Reasons for vaccine refusal or hesitancy (n=150)* } \\
\hline I do not think it is necessary & $24(16.0 \%)$ \\
\hline I think that vaccines are harmful & $44(29.3 \%)$ \\
\hline $\begin{array}{l}\text { I do not know where accurate/reliable information } \\
\text { can be obtained from }\end{array}$ & $66(44.0 \%)$ \\
\hline I have heard or read negative information on media & $44(29.3 \%)$ \\
\hline I do not think vaccines are effective & $23(15.3 \%)$ \\
\hline I think that vaccines have severe side effects & $53(35.3 \%)$ \\
\hline Someone told me that vaccines were not safe & $21(14.0 \%)$ \\
\hline $\begin{array}{l}\text { No sufficient information is provided by the Health } \\
\text { Organizations }\end{array}$ & $36(24.0 \%)$ \\
\hline I do not know the content of the vaccines & $72(48.0 \%)$ \\
\hline Trypanophobia & $5(3.3 \%)$ \\
\hline Religious reasons & $5(3.3 \%)$ \\
\hline Religious beliefs/traditional medicine & $7(4.7 \%)$ \\
\hline Do you beleve that chill
\end{tabular}

Do you believe that childhood vaccines can protect children from severe diseases?

\begin{tabular}{ll}
\hline Yes & $771(74.6 \%)$ \\
\hline No & $78(7.6 \%)$ \\
\hline No idea & $184(17.8 \%)$ \\
\hline
\end{tabular}

Have you ever heard or read negative information on childhood vaccines?

\begin{tabular}{lc}
\hline Yes & $233(22.6 \%)$ \\
\hline No & $800(77.4 \%)$ \\
\hline \multicolumn{2}{l}{ Do you think childhood vaccines should be mandatory? } \\
\hline Yes & $518(50.1 \%)$ \\
\hline No & $182(17.6 \%)$ \\
\hline Not sure & $333(32.2 \%)$ \\
\hline
\end{tabular}

*More than one option was marked 
could protect against severe diseases than those who had no idea about this subject (Table 4).

The acceptance of the COVID-19 vaccine was higher in men (OR: 1.41, 95\% CI: 1.06-1.87), in those who assumed that the COVID-19 virus was of a natural origin (OR: 1.47,

Table 3. Opinions of the participants about the COVID-19 disease and vaccine.

\begin{tabular}{ll}
\hline Variables & $\begin{array}{l}\text { Number } \\
\text { (percentage) }\end{array}$ \\
\hline What do you think the origin of the COVID-19 virus is? \\
\hline An artificial virus & $639(61.9 \%)$ \\
\hline A natural virus & $135(13.1 \%)$ \\
\hline Not sure/no idea & $259(25.1 \%)$ \\
\hline What is your source of information regarding the COVID-19 \\
vaccine? & $747(72.3 \%)$ \\
\hline Social media & $679(65.7 \%)$ \\
\hline Television & $663(64.2 \%)$ \\
\hline Statements of the Ministry of Health & $357(34.6 \%)$ \\
\hline Scientific research papers & $164(15.9 \%)$ \\
\hline Have you caught the COVID-19 disease? & $869(84.1 \%)$ \\
\hline Yes & $238(36.3 \%)$ \\
\hline No & $21(3.2 \%)$ \\
\hline Has anyone got sick severely or died due to COVID-19 in your \\
immediate environment?
\end{tabular}

Have you ever heard or read negative information on the COVID19 vaccine?

\begin{tabular}{lr}
\hline Yes & $598(57.9 \%)$ \\
\hline No & $435(42.1 \%)$ \\
\hline Do you think the COVID-19 vaccine should be mandatory? \\
\hline Yes & $257(24.9 \%)$ \\
\hline No & $477(46.2 \%)$ \\
\hline Not sure & $299(28.9 \%)$ \\
\hline *More than one option was marked. & \\
**The vaccine not being domestic, the thought of chip insertion, believing \\
that recovery will be easy due to the young age, trypanophobia, a decrease \\
in cases, thought of genetic modification via the vaccine, concern about how \\
the life will be after the vaccination, mutagenic characteristic of the virus, etc
\end{tabular}

95\% CI: 1.03-2.48), in those who obtained information on the COVID-19 vaccine from the Ministry of Health (OR: $1.61,95 \%$ CI: $1.37-2.48)$, and in those who made search in scientific papers (OR: 1.28, 95\% CI: 1.00-1.76) (Table 5).

People who hesitated/refused childhood vaccines had a 12.8 times higher risk of hesitating/refusing the COVID-19 vaccine than those who accepted them $(\mathrm{p}<0.001)$.

\section{Discussion}

Since individuals aged between 18 and 25 years interact more with social media and take important decisions that will direct their lives due to being in the period of development, this age group constitutes the key point to maintain a healthy life. There is no evidence, which reveal hesitancy and refusal for childhood vaccines and the COVID-19 vaccine in a similar age group.

The vaccine hesitancy rate was $10 \%$ in a study, which was carried out to determine the hesitancy of students (mean age 20.62 \pm 2.02 ) for childhood vaccines in the Faculty of Health Sciences of a university in Turkey. ${ }^{[18]}$ In a recent study on parents aged between 21 and 53 years, who presented to the family health center in a province of Turkey, the overall hesitancy rate was obtained as $13.7 \% \cdot{ }^{[19]}$ In a population-based study performed by Guay et al. ${ }^{[20]}$, the overall vaccine hesitancy rate was $32.2 \%$, whereas the hesitancy rate of the 18-29 age group was $18.8 \%$. Although the difference was not statistically significant, this age group had the least hesitancy. However, another population-based study found the overall vaccine hesitancy rate as $19.5 \%$ among adults and reported that the probability of vaccine hesitancy considerably increased at younger ages. In the same study, Repalust et al. ${ }^{[21]}$ stated that high vaccine hesitancy rates at younger ages might result from the possibility of higher acceptance of inaccurate information circulating among online or offline peer groups due to the wish of young people to learn more about childhood vaccines. Thus, our study also found that the vaccine hesitancy/refusal possibility increased when negative information was received. The vaccine hesitancy rate for childhood vaccines was $11.4 \%$ in this study, which we conducted on individuals aged between 18 and 25 years. The rates in the literature studies and studies in Turkey are similar, but there are differences in the vaccine hesitancy rates in this age group across the world, which may have arisen from socio-cultural differences.

There are no studies revealing the refusal rates for childhood vaccines in the 18-25 age group in Turkey. However, the vaccine refusal rates generally vary between $4.0 \%-7.7 \%$ in the studies conducted on parents and individuals above $18 .^{[22-24]}$ In our study, the ratio of individuals who refused childhood vaccines or thought of refusing them when they had children was $3.15 \%$. 
Although partially, our study indicates that the low rates of those who approve childhood vaccines currently or in the future when they have a child (68.8\%) and those who do not want vaccination may result from the presence of individuals who have never thought about the vaccination of their children $(16.7 \%)$ in this age group. In studies on the general population and parents in the world, the refusal rates of childhood vaccines range between $6.3 \%$ and $18.0 \%{ }^{[21,25,26]}$ In our study, the following three reasons were the most common reasons for the refusal and hesitancy for childhood vaccines: "not knowing the content of the vaccine," "not knowing where accurate/ reliable information can be obtained from," and "thinking that vaccines have severe side effects." The studies in the literature have obtained similar results. ${ }^{[18-21,23]}$ These results show that factors influencing vaccination acceptance and hesitancy may appear in compliance with the model set forth by SAGE, in different forms as per location and time, but due to the same reasons. ${ }^{[17]}$

This study reported that $36.6 \%$ of the participants thought about having the COVID-19 vaccine, while $28.6 \%$ would refuse it, and $34.8 \%$ hesitated about this

Table 4. Factors influencing the acceptance and hesitancy/refusal for childhood vaccines.

\begin{tabular}{|c|c|c|c|c|}
\hline Characteristics & $\boldsymbol{\beta}$ & OR & $95 \% \mathrm{CI}$ & p-value \\
\hline Age & -0.12 & 0.88 & $0.79-0.99$ & 0.03 \\
\hline \multicolumn{5}{|c|}{ Thinking that they may protect against severe diseases } \\
\hline No idea & Ref & & & \\
\hline No & -0.61 & 0.54 & $0.27-1.06$ & 0.76 \\
\hline Yes & 2.81 & 16.75 & $10.09-27.82$ & $<0.001$ \\
\hline \multicolumn{5}{|c|}{ Having heard or read negative information } \\
\hline No & Ref & & & \\
\hline Yes & -1.22 & 0.29 & $0.18-0.46$ & $<0.001$ \\
\hline
\end{tabular}

$\beta$ : $\beta$ coefficient, OR: Odds ratio, CI: Confidence interval, Ref: Reference, vaccine hesitancy/refusal $=0$, vaccine acceptance $=1$

Table 5. Factors influencing the acceptance and hesitancy/refusal for the COVID-19 vaccine.

\begin{tabular}{|c|c|c|c|c|}
\hline Characteristics & $\beta$ & OR & $95 \%$ CI & p-value \\
\hline \multicolumn{5}{|l|}{ Gender } \\
\hline Female & Ref & & & \\
\hline Male & 0.34 & 1.41 & $1.06-1.87$ & 0.01 \\
\hline \multicolumn{5}{|l|}{ Education level } \\
\hline High school and below & -0.89 & 0.40 & $0.26-0.62$ & $<0.001$ \\
\hline Associate degree & -0.28 & 0.75 & $0.56-1.00$ & 0.05 \\
\hline Bachelor's degree and above & Ref & & & \\
\hline \multicolumn{5}{|l|}{ COVID-19 origin } \\
\hline Natural & 0.47 & 1.60 & $1.03-2.48$ & 0.03 \\
\hline Artificial & -0.29 & 0.74 & 0.54-1.02 & 0.06 \\
\hline Not sure & Ref & & & \\
\hline \multicolumn{5}{|c|}{ Obtaining information from social media } \\
\hline No & Ref & & & \\
\hline Yes & -0.44 & 0.63 & $0.47-0.85$ & 0.003 \\
\hline \multicolumn{5}{|c|}{ Obtaining information from the statements of the Ministry of Health } \\
\hline No & Ref & & & \\
\hline Yes & 0.61 & 1.84 & $1.37-2.48$ & $<0.001$ \\
\hline \multicolumn{5}{|c|}{ Obtaining information from scientific research papers } \\
\hline No & Ref & & & \\
\hline Yes & 0.28 & 1.33 & $1.00-1.76$ & 0.04 \\
\hline \multicolumn{5}{|c|}{ Having heard or read negative information on the COVID-19 vaccine } \\
\hline No & Ref & & & \\
\hline Yes & -0.57 & 0.56 & $0.42-073$ & $<0.001$ \\
\hline
\end{tabular}

$\beta: \beta$ coefficient, OR: Odds ratio, CI: Confidence interval, Ref: Reference, vaccine hesitancy/refusal $=0$, vaccine acceptance $=1$ 
issue. In the literature, there are studies on the general population. However, when separated into age groups, the acceptance rate of the COVID-19 vaccine was found as $73 \%$, the refusal rate as $12 \%$, and the hesitancy rate as $15 \%$ in the $18-24$ age group in a study conducted in the European countries. ${ }^{[27]}$ In a study performed in France, the refusal rate of the COVID-19 vaccine $(19.8 \%)$ was found to be less in the 18-24 age group than in the general population. ${ }^{[28]}$ In a large-scale study carried out in 19 countries, most of which had a high COVID-19 load, the probability of the vaccine acceptance by individuals aged 25-54, 55-64, and 65+ was observed to be higher than individuals aged between 18 and 24 years. ${ }^{[29]}$ In our study, the high vaccine hesitancy and refusal rates might originate from the ratio of the people who received information from social media regarding the COVID19 vaccine $(72.3 \%)$, which was higher than the ratio of those who obtained information from scientific research papers (34.6\%). Moreover, the facts that this age group thinks the COVID-19 virus is artificial, and that their risk of having a severe disease is low can also increase the hesitancy/refusal rates. ${ }^{[10,30]}$ In our study, in line with the literature, the acceptance rate of the COVID-19 vaccine was higher in men and people with bachelor's/master's degrees. ${ }^{[31]}$ In this study, the reasons for hesitancy/refusal regarding the COVID-19 vaccine originated from distrust and conspiracy theories, which was also consistent with the literature. ${ }^{[27]}$

\section{Conclusion}

Vaccine hesitancy and refusal rates are influenced by many factors in the 18-25 age group, and receiving negative information and conspiracy theories on vaccines increase these rates. On the other hand, not knowing the benefits of childhood vaccines in this age group is also a risk factor that will increase the hesitancy and refusal rates. Accordingly, considerable attention should be paid to providing this age group with training on the benefits of both childhood vaccines and COVID-19 vaccines.

\section{Ethics}

Ethics Committee Approval: Institutional Review Board of Baskent University (project no: KA21/33).

Informed Consent: Informed written consent was obtained before oparation from all individual participants included in the study.

Peer-review: Externally peer-reviewed.

\section{Authorship Contributions}

Concept: G.S., E.D., R.A., Design: G.S., E.D., R.A., Data Collection or Processing: G.S., E.D., R.A., Analysis or Interpretation: G.S., E.D., R.A., Literature Search: G.S., E.D., R.A., Writing: G.S., E.D., R.A.
Conflict of Interest: No conflict of interest was declared by the authors.

Financial Disclosure: Institutional Review Board of Baskent University (project no: KA21/33) and supported by the Research Fund of Baskent University.

\section{References}

1. Öztürk Y. Halk Sağlığında Hedef, Amaç ve İlkeleri. İçinde: Öztürk, Y, Günay O, editörler. Halk Sağlığı: Genel Bilgiler. Kayseri; Erciyes Üniversitesi Yayınları; 2011;13-25. [CrossRef]

2. Andre FE, Booy R, Bock HL, Clemens J, Datta SK, John TJ, et al. Vaccination greatly reduces disease, disability, death and inequity worldwide. Bull World Health Organ. 2008;86(2):1406. [CrossRef]

3. Wilson SL, Wiysonge C. Social media and vaccine hesitancy. BMJ Glob Health. 2020;5(10):e004206. [CrossRef]

4. Kader Ç. Anti-vaccination: vaccine hesitancy and refusal. ESTÜDAM Halk Sağlığı Derg. 2019;4(3):377-88.[CrossRef]

5. Jacobson RM, Sauver JLS, Rutten LJF. Vaccine hesitancy. Mayo Clin Proc. 2015;90(11):1562-8.

6. Özceylan G, Toprak D, Esen ES. Vaccine rejection and hesitation in Turkey. Hum Vaccines Immunother. 2020;16(5):1034-9. [CrossRef]

7. Roozenbeek J, Schneider CR, Dryhurst S, Kerr J, Freeman ALJ, Recchia G, et al. Susceptibility to misinformation about COVID-19 around the world. R Soc Open Sci. 2020;7(10):201199. doi: 10.1098/rsos.201199. [CrossRef]

8. Topçu İ, Nasuhbeyoğlu N. COVID-19 vaccine research and ethical issues in the context of gene editing technologies. Anatol Clin J Med Sci. 2020;25(3):274-84. [CrossRef]

9. Corona aşısı denemelerinden kötü haber! Bir gönüllü hayatını kaybetti. Son Erişim Tarihi: 26.02.2021. Erişim Adresi: https:// www.sozcu.com.tr/2020/dunya/corona-asisi-denemelerindenkotu-haber-bir-gonullu-hayatini-kaybetti-6092008/.[CrossRef]

10. Salali GD, Uysal MS. COVID-19 vaccine hesitancy is associated with beliefs on the origin of the novel coronavirus in the UK and Turkey. Psychol Med. 2020:1-3. doi: 10.1017/ S0033291720004067. Epub ahead of print. [CrossRef]

11. Summary WHO SAGE conclusions and recommendations on Vaccine Hesitancy. Last Accessed Date: 26.02.2021. Available from: https://www.who.int/immunization/programmes_systems/ summary_of_sage_vaccinehesitancy_2pager.pdf

12. Improving vaccination demand and addressing hesitancy. Last Accessed Date: 26.02.2021. Available from: https://www. who.int/teams/maternal-newborn-child-adolescent-healthand-ageing/maternal-health/about/essential-programme-onimmunization. [CrossRef]

13. Coronavirus disease (COVID-19) Last Accessed Date: 26.02.2021. Available from: https://www.who.int/news-room/qa-detail/coronavirus-disease-covid-19

14. Covid-19 (Sars-Cov-2 Enfeksiyonu) Genel Bilgiler, Epidemiyoloji Ve Tanı. Son Erişim Tarihi: 26.02.2021. Erişim Adresi: https://covid19.saglik.gov.tr/Eklenti/39551/0/covid-19re hberigenelbilgilerepidemiyolojivetanipdf.pdf. [CrossRef]

15. Arnett JJ. Emerging adulthood: a theory of development from the late teens through the twenties. Am Psychol. 2000;55(5):469-80. [CrossRef] 
16. Larson HJ, Jarrett C, Schulz WS, Chaudhuri M, Zhou Y, Dube E, et al. Measuring vaccine hesitancy: The development of a survey tool. Vaccine. 2015;33(34):4165-75. [CrossRef]

17. The SAGE Vaccine Hesitancy Working Group. What Influences Vaccine Acceptance:A Model of Determinants of Vaccine Hesitancy. Last Accessed Date: 26.02.2021. Available from: https://www.who.int/immunization/sage/meetings/2013/april/1 Model analyze_driversofvaccineConfidence_22_March.pdf. [CrossRef]

18. Yörük S. Factors associated with childhood vaccine hesitancy and measles vaccine hesitancy among healthcare students. Nurs Health Sci. 2020;22(4):1030-7. [CrossRef]

19. Gunes NA. Parents' Perspectives about Vaccine Hesitancies and Vaccine Rejection, in the West of Turkey. J Pediatr Nurs. 2020;53:e186-94. doi: 10.1016/j.pedn.2020.04.001. [CrossRef]

20. Guay M, Gosselin V, Petit G, Baron G, Gagneur A. Determinants of vaccine hesitancy in Quebec: a large population-based survey. Hum Vaccines Immunother. 2019;15(11):2527-33. [CrossRef]

21. Repalust A, Šević S, Rihtar S, Štulhofer A. Childhood vaccine refusal and hesitancy intentions in Croatia: insights from a population-based study. Psychol Health Med. 2017;22(9):104555. [CrossRef]

22. Oğuzöncül AF, Dartilmak T, Deveci SE, Pirinçci E. Evaluation of the knowledge and attitudes on vaccination of the patients and their relatives who admitted to the vaccine stand. ESTÜDAM Halk Sağlığı Derg. 2019;4(3):287-93. [CrossRef]

23. Hazır E. 0-24 Aylık Bebek/Çocukların Ebeveynlerinin Aşı Red Siklığı ve Nedenleri [Yüksek Lisans Tezi]. İstanbul: Okan Üniversitesi Sağlık Bilimleri Enstitüsü; 2018. [CrossRef]

24. Sarıgül B. Aile hekimliğine başvuran bireylerin aşı hakkındaki davranış, bilgi ve tutumlarının değerlendirilmesi [Tıpta Uzmanlık
Tezi]. Çanakkale: Çanakkale Onsekiz Mart Üniversitesi Tıp Fakültesi, Aile Hekimliği Ana Bilim Dalı; 2019. [CrossRef]

25. Napolitano F, D’Alessandro A, Angelillo IF. Investigating Italian parents' vaccine hesitancy: A cross-sectional survey. Hum Vaccines Immunother. 2018;14(7):1558-65. [CrossRef]

26. Costantino C, Caracci F, Brandi M, Bono SE, Ferro A, Sannasardo $\mathrm{CE}$, et al. Determinants of vaccine hesitancy and effectiveness of vaccination counseling interventions among a sample of the general population in Palermo, Italy. Hum Vaccines Immunother. 2020;16(10):2415-21. [CrossRef]

27. Neumann-Böhme S, Varghese NE, Sabat I, Barros PP, Brouwer W, van Exel J, et al. Once we have it, will we use it? A European survey on willingness to be vaccinated against COVID-19. Eur J Health Econ HEPAC Health Econ Prev Care. 2020;21(7):977-82. [CrossRef]

28. Schwarzinger M, Watson V, Arwidson P, Alla F, Luchini S. COVID-19 vaccine hesitancy in a representative working-age population in France: a survey experiment based on vaccine characteristics. Lancet Public Health. 2021;6(4):e210-21. doi: 10.1016/S2468-2667(21)00012-8. [CrossRef]

29. Lazarus JV, Ratzan SC, Palayew A, Gostin LO, Larson HJ, Rabin $\mathrm{K}$, et al. A global survey of potential acceptance of a COVID-19 vaccine. Nat Med. 2021;27(2):225-8. [CrossRef]

30. Sallam M, Dababseh D, Eid H, Al-Mahzoum K, Al-Haidar A, Taim D, et al. High rates of COVID-19 vaccine hesitancy and its association with conspiracy beliefs: a study in Jordan and Kuwait among other Arab countries. Vaccines (Basel). 2021;9(1):42. [CrossRef]

31. Malik AA, McFadden SM, Elharake J, Omer SB. Determinants of COVID-19 vaccine acceptance in the US. EClinicalMedicine. 2020;26:100495. [CrossRef] 